\title{
ENRICHING THE INFORMATION SYSTEMS CURRICULUM TO ENABLE DIGITAL INNOVATION CAPACITY
}

\author{
C. L. van den Berg \\ Department of Information Systems \\ University of the Western Cape \\ Cape Town, South Africa \\ e-mail: cvandenberg@uwc.ac.za
}

\section{ABSTRACT}

The diffusion of technology is opening up numerous opportunities to transform business and society through digital innovations are emerging as a result of the diffusion of technology. Information Systems (IS) education needs to prepare students to apply technology to improve the effectiveness of business, the environment and society. Their ability to utilise digital innovations will be at the crux of the transition to a digital world because they are instructed in both Information Technology (IT) and business. They should therefore have the ability to identify the value of advances in technology to meet an unmet organisational or societal need. Graduates in IS need to play a leading role as the innovators of the future and the teaching and learning environment needs to prepare them for this uncertain, complex and ambiguous world. Drawing on findings from a PhD study, this article explores complexities of our higher education environment, coupled with the explosion of digital technologies and, at the centre, the students and their well-being. The intention is to explore the skills required to enhance the capability of IS students to participate in, and ultimately orchestrate, digital transformation in business and society. A design-based research (DBR) approach was applied in a mixed-methods design via three iterations during 2016 and 2017. The study produced scientific outputs resulting in eight design principles to capacitate students for the future world of work.

Keywords: digital innovation, information systems curriculum, future skills, graduate development, student well-being

\section{INTRODUCTION}

Digital innovation as a result of technological diffusion is opening up multiple opportunities for business and society to be transformed. New technologies range from mobile, cloud, social media and analytics, to wearable devices, 3D printing and the full digitisation of economies (Benkert and Van Dam 2015; Fichman, Dos Santos and Zheng 2014). The automation of work, new knowledge work tools, the emergence of intelligent processes, more precise analytical capabilities, a new age of artificial intelligence (AI), consumer gadgetry, instant communication and boundless information will have a significant impact on the well-being of society. 
Information Systems (IS) education ought to equip students to use technology to improve the effectiveness of business, the environment and society, with digital innovation being at the heart of this transformation (Fichman et al. 2014). Drawing on findings from a $\mathrm{PhD}$ study, this article explores the disparity between the unprecedented potential of digital markets and the skills gap in South Africa to harness these opportunities.

The problem of how to teach the required skills to equip IS students to better perform their future roles in the digital economy is multifaceted. A review of the literature reveals very little research in terms of how this can be done. A proposed update to the international IS curriculum 2015 , similar to the 2010 update, contains limited guidance on digital transformation or digital innovation (Topi et al. 2010; Rosenthal and Dhariwal 2015). This prompted the question: How should digital innovation skills be taught to South African IS students? To answer this question, the impact of global trends in digital innovation on the IS curriculum, the skills required to develop competent digital innovators, and the teaching and learning interventions required in IS were reviewed.

The findings of the study are highlighted in this article via engagement with the literature and extracts from data collected during an iterative design-based research (DBR) study during 2016 and 2017. The article concludes with an overview of the eight design principles developed to enrich the IS curriculum in order to enable digital innovation capacity.

\section{ENGAGEMENT WITH LITERATURE}

\section{The impact of digital innovation on the IS curriculum}

Digital technologies can be defined as the blending of information, computing, communication and connectivity technologies (Bharadwaj et al. 2013). Innovation is an idea, practice or object perceived as new (Rogers 1995). A digital innovator has the ability to join two things together, such as knowledge of technological advances and their possibilities, and an astute insight into some unmet organisational or societal need (Fichman et al. 2014).

The digital revolution creates employment opportunities for highly skilled workers in entirely new occupations and industries. Many occupations, now in high demand, did not exist a couple of years ago, and children entering school will probably embark on jobs that do not yet exist. This digital revolution requires governments, business and higher education to collaborate in order to anticipate trends and prepare for future skills requirements to ensure the development of graduates (Montresor 2016).

The teaching of digital innovation requires an understanding and integration not only of the subject matter, but also of how students develop their skills, habits, practices and 
conceptions of learning in a digital age. The mode of learning needs to reflect the experience of learning in a digital age (Sharpe, Beetham and De Freitas 2010, 86).

The development of a digital innovation agenda within the IS curriculum has to be prioritised. Students need to be prepared for the digital economy through the design of a participative, digitally enabled, collaborative learning environment. Higher education institutions (HEIs) are forced to experiment with new formats and strategies for learning and teaching to be able to offer relevant, effective and high-quality learning experiences in the future. This will require more flexibility to support both individual and industry needs in order to better align supply and demand via information and communication technologies (ICTs) (Redecker et al. 2011).

Imparting digital innovation capability not only requires teaching about technology (content), but importantly also teaching with technology (pedagogy). A new culture of learning in the $21^{\text {st }}$ century call for the integration of knowledge from different domains: knowledge of student thinking and learning, knowledge of subject matter, and knowledge of technology (Koehler and Mishra 2009).

Curriculum guidelines for undergraduates in Information Systems (IS) have been developed by the Association for Computing Machinery (ACM) and the Association for Information Systems (AIS) (Topi et al. 2010). These guidelines have not been updated since 2010, and contain very limited guidance on course design insofar as digital business innovation is concerned. Digital business innovation needs to form part of the IS curriculum via the adjustment of all IS courses to include a greater innovation orientation. This can be phased in via the introduction of electives in digital business innovation. There ought to be a focus on instruction in techniques to actively involve students in the innovation process, such as prototyping, agile development and design thinking, along with the exposure of students to realworld problems (Fichman et al. 2014).

This section has introduced the importance of the teaching of digital business innovation to IS students. The next section will discuss the skills required of IS students to become more competent digital innovators.

\section{Skills required to develop competent digital innovators}

The type of skills that students will need to develop in the digital economy is collectively referred to as " $21^{\text {st }}$-century skills" $\left(21^{\text {st }} \mathrm{CS}\right)$. From the 1990 s, many countries started applying $21^{\text {st }} \mathrm{CS}$ to their curriculum policies (P21 2015). As such, increased pressure by industry and government was placed on educators to develop $21^{\text {st }} \mathrm{CS}$ in pedagogy, curriculum and assessment resulting in a number of different frameworks. This article explored a number of 
frameworks and the most comprehensive was deemed to be the framework of Kereluik et al. (2013). This framework consists of foundational, meta- and human knowledge.

Students require foundational knowledge that consists of core content, cross-disciplinary and digital knowledge. One can argue that core content knowledge will continuously change in an IS curriculum due to the rapid advancement of technology. Furthermore, the methods and techniques of obtaining, expressing and manipulating knowledge will also continue to evolve. This does not imply that students do not need deep disciplinary knowledge, merely that more authentic disciplinary inquiry needs to take place (Kereluik et al. 2013).

The development of cross-disciplinary knowledge talks to the concept of T-shaped individuals. This can be explained as individuals who bring with them a deep understanding of at least one field (vertically), but have the versatility to understand and participate in a broader range of disciplines (horizontally) (Van Dijk 2010). Information Systems students need to be completely confident with the use of digital technologies and have a broad understanding of the available technology. Students need to be able to track changes in technology and be familiar with the applications of new technology within a business environment. Digital knowledge requires a deep understanding of the entire digital environment and the ability to quickly adopt new technology and co-create content. Students also need to master online communication etiquette, and digital rights and responsibilities (Adams Becker et al. 2017).

For meta-knowledge, or the knowledge "to act", creativity, innovation, problem solving, critical thinking, communication and collaboration are required. These skills are not unique to the $21^{\text {st }}$ century, but have been amplified by digital transformation because of the large amounts of information available and the need for the ability to distinguish the reliability thereof, as well as open communication and collaboration across a wide variety of platforms (Kereluik et al. 2013). Meta-knowledge requires students to develop skills such as ideation, large-frame pattern recognition and complex communication (Brynjolfsson and McAfee 2014; Cain and Henriksen 2017). In order to develop these skills in students, authentic tasks and assessments are required to enable them to learn and demonstrate such outcomes (Herrington, Reeves and Oliver 2010). In order to develop creativity and innovation skills, deep cognition is required via immersion in an authentic learning environment to allow students to experience the process and reflect upon it, which requires time (Hartman and Darab 2012). Creativity is often emphasised in organisations, but what needs to be pursued actively is innovation. Innovation requires creativity to be effective, and creativity requires innovation to be effected (Briggs 2013).

Globalisation, digital transformation, extreme longevity and Artificial Intelligence will all have an impact on human knowledge. Students need to develop the skills to become lifelong learners in an ever-changing world and have a future-focused mindset. A deep understanding 
of human emotions and human interactions will become more and more important as we march towards the "second machine age" (Kereluik et al. 2013; Brynjolfsson and McAfee 2014; Nanterme and Daugherty 2017).

\section{Teaching and learning interventions required to teach digital innovation}

In order to cultivate capable digital innovators, students need to understand the real-world relevance of their coursework to foster more active learning experiences, both inside and outside the classroom (Johnson et al. 2016). This requires classrooms to move away from the traditional to resemble real-world work and social settings that encourage transdisciplinary problem solving (Green 2015, 16; Adams Becker et al. 2017).

For $21^{\text {st }}$-century learning to be effective, the active involvement of students in their learning is paramount. The design of learning based on how human beings think and learn has been influenced for decades by cognitive psychologists like Vygotsky (1978). Their work has been taken forward, and literature on the nature of thinking, problem solving and reasoning is in abundance, but to actively involve students the importance of an authentic learning environment emerges (Herrington 1997). The application of authentic learning principles was explored to test the application thereof in the design of principles to enable IS students to become capable digital innovators.

The principles of authentic learning, as outlined in Herrington et al. (2010), are described below.

1. Provide authentic contexts that reflect the way the knowledge will be used in real life. The argument is made that students ought to be challenged via realistic levels of complexity in the learning environment and guided in this, as opposed to the oversimplification of complex issues. This will mirror the real-life situation that students will encounter in the workplace, and prepare them to function successfully in the digital economy. Moreover, real-life problem solving is not an individual task, but involves collaboration and a shared consequence. The design ought to be nonlinear and students should have a large number of resources available to them.

2. Provide (an) authentic task/s to enable students to interact with the learning environment and demonstrate their skills and competencies. These need to have real-world relevance, be ill-defined, continue over an extended period of time and be integrated across subject areas.

3. Provide access to expert performances and the modelling of processes by allowing students access to experts within the industry, collaboration with other students and 
facilitation by the lecturer.

4. Provide multiple roles and perspectives to move away from a linear method of instruction, and expose students to different perspectives on the topic and approach it from different angles, using a variety of interpretations.

5. Support the collaborative construction of knowledge tasks in which group work is required to complete tasks, and the appropriate assessment is in place to emphasise whole-group achievement.

6. Promote reflection to enable abstractions to be formed by students whilst they are working within the authentic context completing authentic tasks. They need to be able to go back to any element and reflect on the outcomes thereof, and compare themselves to experts and the other learners, both during the completion of tasks and afterwards.

7. Promote articulation to enable tacit knowledge to be made explicit. Students need to have continuous opportunities to discuss their learnings as their understanding grows within their collaborative groups, and via presentations during class.

8. Provide coaching and scaffolding by the teacher at critical times to support students in their learning by playing the role of a facilitator who guides students and provides resources.

9. Provide for integrated assessment of learning within the tasks to provide the opportunity for students to demonstrate their acquired knowledge as the learning progresses until the final product is delivered. Assignments need to allow enough time for students to collaborate with others. Educators widely acknowledge that assessment is a key driver of student behaviour, and therefore it can play an important role in teaching innovations (Osborne, Dunne and Farrand 2013; Bates 2015, 467). The teaching of digital innovation cannot rely on traditional forms of assessment, as authentic assessment that incorporates group work, problem-based, collaborative and portfolio assessment will be far better suited.

A review of the literature, supported by consultations with industry partners, practitioners and students, resulted in the draft design principles that were tested and refined during the three iterations that took place between 2016 and 2017. These principles included aspects related to team collaboration, opportunities for students to find their own solutions, and the implementation of a working digital innovation within a business. The incorporation of design thinking, and allowing for experimentation whilst authentic tasks culminate in a capstone project, were further aspects to include in the design. Students also needed a formal process of reflection and the opportunity to apply interdisciplinary skills in the course. 


\section{METHODOLOGY}

Design activities are central in many applied disciplines, such as the arts, engineering, education, IS and psychology, because of a focus on the creation of innovative artefacts to solve real-world problems (Hevner and Chatterjee 2010). The merger of IS research within an educational setting supports using a design-based research (DBR) strategy. Within the IS field, DBR places a central focus on the application of human creativity in the construction of artefacts, and for the study of "wicked organisational problems" typical of a digital environment (Hevner and Chatterjee 2010, 11). Design-based research within a teaching and learning environment is ideal for the research and design of a learning environment in which technology plays a major role (Wang and Hannafin 2005), as was the case in this study. The suitability of DBR is further supported by (Amiel and Reeves 2008, 30), who say that "design-based research provides an innovative proposal for research on innovation and education".

In DBR, the researcher collaborates with participants and other stakeholders to improve teaching and learning practices in an interactive, systematic, flexible and iterative way within real-world settings (Herrington and Reeves 2011). The research followed iterative cycles to enrich and update theory based on the data collected (Herrington and Reeves 2011). Both qualitative and quantitative data were collected in a mixed-methods design, following the Triangulation Design: Convergence Model of Creswell and Plano Clark (2011), which allows different but complementary data to be collected and analysed.

\section{Data collection}

Data was collected from multiple sources during three iterations that took place during 2016 and 2017. The first iteration was conducted with a group of IS Honours students in a module titled End User Practical. There were a total of 43 students registered for the module and all students gave their informed consent to be part of the study.

The second iteration took place with a group of 40 third-year IS students during the second semester of 2016. The module was specifically designed to teach digital business innovation, and all students gave their informed consent to participate in the study. The third iteration took place with third-year IS students who enrolled in the Digital Business Innovation capstone course during the second semester of 2017. The study obtained ethics clearance from the university's Research Committee prior to the commencement of the research.

Data sources included pre- and post-course surveys conducted on Google Forms among all students to test skills development. Formal student reflections via weekly online blogs were also analysed. Other forms of data collection included student assignments and results from the 
online assessment submissions and field notes. The application of mixed-methods research can result in rich insights into various phenomena to develop novel theoretical perspectives (Venkatesh, Scott and Barrett 2013).

\section{Data analysis}

Using the design-based research approach, data analysis progressed through a number of iterative cycles and processes. Research aims and key questions guided the analysis of the data, supported by the key theoretical principles informing the design of the intervention.

Quantitative data were analysed to test the reliance on certain skills during an initial assessment, and again at the end of the course. These skills were identified from the literature. A multiple regression equation was applied that estimated the relationship between a dependent variable (Y) (student assessment scores) and the nine independent variables (X) (the skills sets identified).

The analysis helped to identify the skills that were statistically significant using the pvalue to test the null hypothesis. If a variable has a low p-value $(<0.05)$ it indicates that the null hypothesis can be rejected and the variable therefore is a meaningful addition to the framework.

The researcher was actively involved in the data gathering in order to keep the data as close as possible to the actual events. The steps prescribed by Miles and Huberman (1994) to systematically organise the data were applied in the qualitative data analysis.

Step 1: Reflect on the data received, organise data systematically, and try to discover emerging patterns.

Step 2: Interpret the data collected against the key principles informing the design. This would include coding the data in relation to the key pedagogical and design principles identified in the literature, as well as identifying new and emerging principles from the implementation process.

Step 3: Follow the data analysis phases indicated in the DBR approach through the iterative cycles. This iterative process enables the researcher to become more grounded in the data and to develop a deeper understanding of the phenomenon as richer concepts emerge.

The analysis of qualitative data can provide richer descriptions and explanations that will support the findings of the quantitative analysis. Words from the research participants can provide a more convincing argument than numbers (Braun and Clarke 2006). However, qualitative analysis can be criticised for lacking in methodological rigour and can increase 
researcher subjectivity (Gray 2004, 320). The process of analysis has to address the representativeness and the trustworthiness of the data. This requires the quality to be assessed and weighted (McKenney and Reeves 2012, 101). All datasets were analysed to look for patterns and similarities in the responses to ensure that they represented the views of the entire group.

\section{FINDINGS TO TEST SKILLS DEVELOPMENT AND AUTHENTIC LEARNING AGAINST DESIGN PRINCIPLES}

The findings from the regression analysis to test the students' skills development across the three iterations are illustrated in Table 1.

Table 1: Regression results

\begin{tabular}{|l|c|c|c|c|c|c|}
\hline \multirow{2}{*}{ Skills } & \multicolumn{2}{|c|}{ Iteration 1: $\mathbf{P}$ value } & \multicolumn{2}{c|}{ Iteration 2: $\mathbf{P}$ value } & \multicolumn{2}{c|}{ Iteration 3: $\mathbf{P}$ value } \\
\cline { 2 - 7 } & $\mathbf{P r e}$ & $\mathbf{P o s t}$ & $\mathbf{P r e}$ & $\mathbf{P o s t}$ & Pre & Post \\
\hline Core content & $\mathbf{0 . 0 3 4 ^ { * }}$ & 0.764 & 0.325 & $\mathbf{0 . 0 5 4}$ & 0.387 & $\mathbf{0 . 0 4 8}$ \\
\hline Digital / ICT & 0.231 & 0.701 & 0.756 & 0.747 & 0.179 & 0.614 \\
\hline Cross-disciplinary & $\mathbf{0 . 0 5 0}$ & 0.407 & $\mathbf{0 . 0 0 3}$ & 0.591 & $\mathbf{0 . 0 1 1}$ & 0.330 \\
\hline $\begin{array}{l}\text { Communication I } \\
\text { collaboration }\end{array}$ & 0.320 & 0.898 & 0.410 & 0.385 & 0.334 & 0.939 \\
\hline $\begin{array}{l}\text { Problem solving / critical } \\
\text { thinking }\end{array}$ & 0.351 & 0.706 & 0.814 & 0.317 & 0.037 & $\mathbf{0 . 0 0 9}$ \\
\hline Innovation / creativity & 0.117 & $\mathbf{0 . 0 4 7}$ & 0.803 & $\mathbf{0 . 0 5 1}$ & $\mathbf{0 . 0 0 1}$ & $\mathbf{0 . 0 0 0 4}$ \\
\hline Life / job skills & 0.493 & 0.516 & $\mathbf{0 . 0 4 0}$ & 0.230 & 0.430 & $\mathbf{0 . 0 0 1}$ \\
\hline Emotional intelligence & 0.152 & 0.626 & 0.792 & 0.452 & 0.224 & 0.173 \\
\hline Cultural competency & 0.437 & 0.811 & 0.639 & 0.414 & 0.227 & $\mathbf{0 . 0 0 4}$ \\
\hline
\end{tabular}

*Highlighted areas: $p$-value $(<0.05)$

The variables that stand out in the initial versus the final survey in each iteration and that are statistically significant are highlighted. In all three iterations, students had an accurate perception of the skills required for cross-disciplinary knowledge during the initial assessment. The design of the initial assessments in the course is therefore satisfactory in its ability to draw on the students' abilities to use their interdisciplinary skills.

The design principles were updated and refined during each iteration, and the results from the third iteration prove this finding. The presence of innovation/creativity and problem solving/critical thinking, together with cross-disciplinary skills in the first assessment in the final iteration, is an improvement on the first two iterations. These skills are the correct skills to emerge from the start of the course.

During the third iteration, the second survey produced a statistically significant outcome for core content, problem solving/critical thinking, creativity/innovation, life and job skills, as 
well as cultural competency. This result points to a significant improvement from the first two iterations and shows a far more balanced development of student competencies. The updated design principles that resulted from the findings in the third iteration are depicted in Table 2.

\section{Qualitative analysis of authentic learning that took place}

The qualitative findings from the third iteration are presented to provide an overview of how authentic learning applied to the updated design principles.

\section{Authentic context}

A similar formula was applied to each iteration, whereby students were required to implement a real-life digital innovation within an organisation, and the project was rolled out during the semester. The capstone project consisted of a number of tasks that were performed individually and within teams. A blended-learning environment was established to encourage teams to collaborate both online and during face-to-face sessions with team members, peers, the lecturer and clients.

The students were very responsive to the creation of an authentic context and felt that they benefited from a real project environment.

The quotes are untouched to allow for authenticity, because they are extracted from the students' conversational writing to one another in their weekly blogs.

"I am now even more hungry than I was before ... all thanks to the knowledge I have gained from having to actually do a project for an existing business, bringing about improvements and gain both academic and interpersonal skills from presenting in class and to the business itself." (BM)

"This was not just some little assignment, but actually it was more about changing the business for the better into a techno-friendly organization and how the business could accept that change." (TG)

"I would not change a thing about this learning environment as I feel it produces positive results. It also makes a student want to work hard and for me it makes me want to learn new things every day. It's one of the best lecture environments I've been in." (DW)

\section{Access to expert performance}

This element was built into the design principles because a working digital innovation needs to be implemented via a design-thinking process and the students are required to formally reflect on the process.

The lecturer and industry partners need to perform the role of experts and assist students when they require assistance with the modelling of processes. Class discussions and presentations further assisted the students to acquire digital innovation skills. 
"The lecturer used the space which allowed us to be creative and be free to express our feelings and be ourselves. A space to grow and become better than we were. The lecturer knew what she was lecturing about, and wanted us to see the big picture of the module itself." (ZG)

"For the last couple of weeks, I've become more use to working in a group and presenting our work to the class after every lecture. It's definitely an interesting way to gain knowledge from your peers and also have the opportunity to grade and criticize their work and, as a class, brainstorm ideas on how they can improve their work." (KU)

\section{Multiple roles and perspectives}

The students were partnered with businesses from a variety of industries and encouraged to actively familiarise themselves with the industry via exercises in class and engagement with the clients. Teams presented the findings of their analysis in class and were required to engage with their industry partner's clients.

The students were required to perform specific roles within the project teams by applying an agile project methodology. This enabled them to experience a project environment and take accountability for their role in the successful implementation of the project. At the completion of the project, the different role players provided feedback to others on their interpretation of the role and their overall experience within the team. To incorporate this, the final section of the project report included lessons learned as individual team members during the project, as well as lessons learned as a team.

"Teamwork called upon us to merge our knowledge and ideas, which intensified the overall talent of the team. The willingness to share is incremental. It has become clear to us that as a group that works well together, we can achieve more than working individually. A broader range of skills was applied to all project activities and sharing and discussing ideas played a pivotal role in deepening our understanding of all subject areas." (TB)

Different perspectives on what will be successful and what not were encouraged, and the student teams had to demonstrate that they explored problems using multiple sources and opinions. This was built into the feedback presentations, and other teams were required to provide feedback on progress and give their views on what will be successful for other teams and why.

"During the lecture, I enjoy doing activities that uplifts one's capability and to continue knowing how you influence others and how they help you see beyond your own capabilities." (MB)

\section{Collaborative learning environment}

The creation of a collaborative learning environment is an essential element to enable IS students to become competent digital innovators. This element was therefore translated into one 
of the design principles, and the aspects to include in the learning environment were explored during the three iterations. These included teams to be formed for student projects, where students were required to perform tasks in teams and were assessed on their success in this regard. The incorporation of peer reviews and of blended learning facilitated both online and face-to-face collaboration.

Teamwork can create conflict and misunderstanding and needs to be managed by the facilitator to ensure that students learn from the experience. The reality is that students will be required to work in teams in all future endeavours, and it is recommended that they reflect on the process and document their individual and collective lessons learned. This was done in the final document, and the students were required to include their individual and collective findings and present these to the rest of the class.

"Firstly, the project has provided a platform to improve weaknesses as well as teaching other lessons along the process. The project provided a chance to improve effective communicating with team members, implementation of mutual understanding and lastly, clearly communicating and voicing thoughts. Moreover, the lessons learnt during this process are the importance of setting timeframes for the project, importance of empathizing (understanding others' point of view) with fellow team members, being a team player (supporting others on task delegated to them without hesitation) as well as learning to adjust to the requirement of the work and workload." (XS)

"I have always been taught that communication is important in every relationship you build, whether it is work or personal. Well, communication is key which is the greatest lesson I learnt during the process of completing this assignment. With all the ups and downs I learnt that sometimes when you voice out your views there is someone willing to listen and there is always someone that will teach you something." (SM)

\section{Reflection}

The implementation of a formal process of reflection was incorporated into the design principles. Students were required to reflect on their weekly progress via an individual online blog. This was incorporated from the first iteration and was deemed successful from the start. A few things were adjusted during the course of the three primary iterations to make the process more successful. The most important aspect was to provide clear guidance in the rubric in terms of the expected outcomes, and to provide a certain amount of structure for the students to follow. The structure was too rigid during the first iteration, and more freedom to explore different mediums was allowed in subsequent iterations.

"Blogging has taught me so much; I definitely will continue to do so. It is a space where I can express my views freely. I am happy here, which is what I strive for in this life, to be happy and content with all I do." (SL) 
A screen shot taken of one of the blogs can be viewed below as an example of the layout.

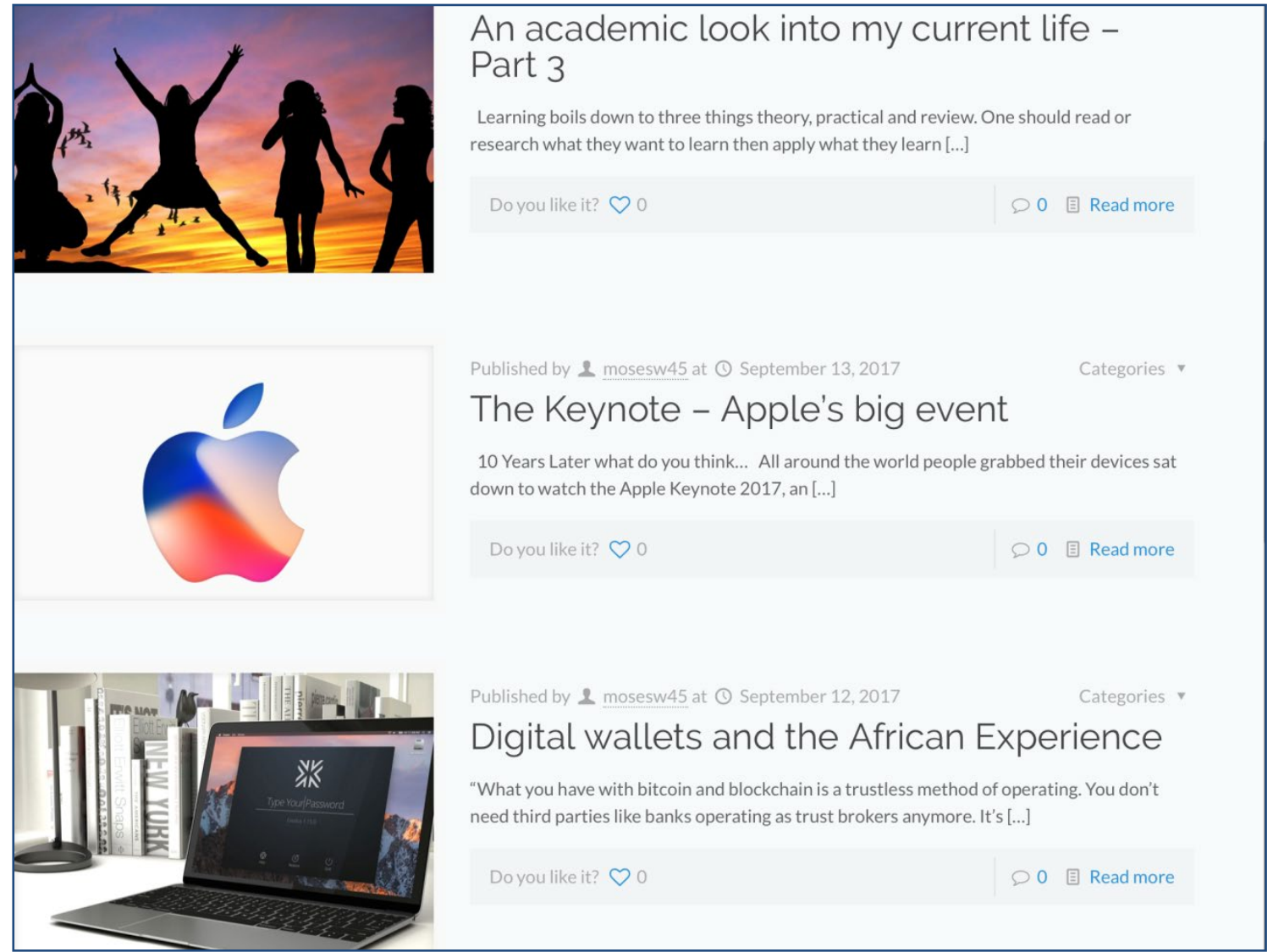

Figure 1: Student blog, iteration 4

\section{Articulation to enable tacit knowledge to be made explicit}

The students demonstrated their understanding of their digital business innovations for their clients via weekly oral presentations on their progress. An online environment was further established to allow the students an opportunity to update their project documentation and to receive feedback on their progress. The teams were encouraged to participate actively and to share their thinking and knowledge during discussions in class and online. The students were coached in expressing their thoughts and opinions and not being afraid to voice their opinions, and the class environment allowed constant interaction between group members.

"One thing I learnt is that you need to learn to stand up for yourself, especially if you are in a group with a lot of males. They tend to want to dominate, to take over and make the project theirs, and as females we are simply accessories that are there to do the admin. You need to learn to voice your opinion, make changes where you see the need to and not allow yourself to be bullied by your male colleagues, and that is what I take into the future." (SL)

"Suppose you were a person who learnt to enjoy their own space and in most cases, prefers to talk less when around people. You tried every method to be a seen as a social person as carefully as you could, until when least expected in all your experiments [sic], a platform is given to you and you notice as time goes on and things are happening that you are changing. This has been the case 
for me when it came to IFS341, being more able to voice my own thoughts, views and values with confidence amongst my team and some of my class mates. Moreover, a leadership role had been offered to me as I had never before wanted to take one as I had struggles [sic] of delegating and voicing my thoughts." (XS)

\section{Coaching and scaffolding}

During the three primary iterations, coaching and scaffolding were elements that required careful balancing and reflection to ensure that the students were supported in their own learning process, with guidance being provided at the right times. It became very important to consciously monitor how teaching, coaching and facilitation contributed both positively and negatively to the students' experience of the course.

During the second iteration, the role of feedback was tested to ensure the right balance of feedback from both the lecturer and others to achieve elements of intrinsic and extrinsic feedback or sustainable feedback. This requires feedback from multiple sources, including peers, industry partners and team members, and from the facilitator to establish conditions in which students can operate with agency (Boud and Molloy 2013).

The feedback provided to students therefore needed to be interrogative to test why certain decisions were made, and to prompt students to substantiate their choices. This was built into the course design from the first iteration, although the true value only started to emerge during the third iteration, when rubrics were adjusted to ensure that the students were measured on the quality of feedback given and the ability to utilise feedback for the further rollout of their projects.

During the third iteration, more care was taken to facilitate relationship building between the industry partners and the teams. The formulation of teams followed a hybrid approach, whereby students could select some members and others were randomly allocated to test the outcome thereof. As the facilitator, it is important to have coaching skills in order to know when to interject, redirect, scaffold or, in rare cases, mediate. It is important to scaffold the roles between the different stakeholders with just enough information and support for students to get started with their projects, but not too much so that they have no decisions to make for themselves (Stansberry 2017).

A blended learning approach to flip the classroom was applied and the students received their learning material prior to face-to-face sessions. The class times were used for the practical application of knowledge and became an interactive space, in which all teams and the facilitator could engage and provide feedback on progress.

"As a slow learner I was accommodated in class the way she teaches accommodated me and made 
me feel welcomed." (BM)

"I'd like to note that I think slides that come with voice notes on them are a lifesaver. It makes it a lot easier for us students to quickly get an idea of what the next class will be on and know where our understanding is lacking beforehand." (ME)

\title{
Authentic assessment
}

The element of authentic assessment requires the assessment of integrated tasks that occur over a sustained period of time and result in a finished, polished product (Herrington et al. 2010). The course was designed to include multiple assessments that were linked to the rollout of the final product/artefact. The assessments were summative to enable the student teams to improve on the final product. The feedback provided enabled students to realise where they needed to improve to provide a better product.

The assessments were linked to the project and each session was devoted to a step in the process, during which students showed progress and obtained feedback.

\begin{abstract}
"We were never reprimanded on the way we saw a certain aspect or topic. This really made me grow as a person as my thoughts were not shot down, but encouraged and praised. I honestly feel that campus should not just be about tests and exams, but it should rather be practical assignments where pupils can go out into the real world and figure out things for themselves." (AB)

"It is evident to me that this course is capable of living up to its stated promise of equipping any student with the knowledge and skills necessary to use technology to improve business, the environment, and society; identifying the value of technology advancement to meet unmet organisational or social need, and thus making us capable of playing leading roles as innovators of the future. Honestly this was the best class I have ever attended in my entire life, no other has been as fruitful and enlightening to attend as it is." (KV)
\end{abstract}

\section{RESULT: UPDATED DESIGN PRINCIPLES RESULTING FROM THE DBR STUDY}

The design principles that were developed and refined during each iteration can be viewed in the Table 2 .

Table 2: Design principles

\begin{tabular}{|c|c|c|c|}
\hline Principle & Description and updates & $\begin{array}{l}\text { Skills sets } \\
\text { required for } \\
\text { principle }\end{array}$ & $\begin{array}{l}\text { Authentic learning } \\
\text { elements to support }\end{array}$ \\
\hline $\begin{array}{l}\text { Ensure } \\
\text { collaboration } \\
\text { takes place }\end{array}$ & $\begin{array}{l}\text { Students need to perform tasks in } \\
\text { teams (provide guidelines for team } \\
\text { construction) } \\
\text { Ensure that students collaborate to } \\
\text { solve problems in class and in projects } \\
\text { - Use peer reviews that are assessed } \\
\text { Within class time, aim to be a facilitator } \\
\text { in student learning, and not the expert } \\
\text { in the room, in order to encourage } \\
\text { experimentation } \\
\text { Use a blended learning environment to } \\
\text { encourage online collaboration and }\end{array}$ & $\begin{array}{l}\text { Collaboration and } \\
\text { communication } \\
\text { Cultural } \\
\text { competency }\end{array}$ & $\begin{array}{l}\text { Authentic tasks - } \\
\text { opportunity to collaborate } \\
\text { Support collaborative } \\
\text { learning } \\
\text { Promote articulation to } \\
\text { enable tacit knowledge to } \\
\text { be made explicit }\end{array}$ \\
\hline
\end{tabular}




\begin{tabular}{|c|c|c|c|}
\hline Principle & Description and updates & $\begin{array}{l}\text { Skills sets } \\
\text { required for } \\
\text { principle }\end{array}$ & $\begin{array}{l}\text { Authentic learning } \\
\text { elements to support }\end{array}$ \\
\hline & $\begin{array}{l}\text { face-to-face collaboration, and assess } \\
\text { Assessments need to include aspects } \\
\text { such as teamwork, work ethic and } \\
\text { collaboration }\end{array}$ & & \\
\hline $\begin{array}{l}\text { Provide } \\
\text { opportunities for } \\
\text { students to find } \\
\text { their own } \\
\text { solutions }\end{array}$ & $\begin{array}{l}\text { Encourage innovation by letting } \\
\text { students take their own initiative } \\
\text { Do not put too much structure in place; } \\
\text { use some scaffolding when required } \\
\text { Let the students discover their own } \\
\text { answers by accessing several different } \\
\text { sources and experimenting with } \\
\text { different techniques to become } \\
\text { comfortable with pivoting, adapting and } \\
\text { changing } \\
\text { Create an online environment in which } \\
\text { students can experiment with solutions }\end{array}$ & $\begin{array}{l}\text { Problem solving } \\
\text { and critical thinking } \\
\text { Creativity and } \\
\text { innovation }\end{array}$ & $\begin{array}{l}\text { Authentic contexts } \\
\text { Authentic tasks - ill- } \\
\text { defined activities } \\
\text { Lecturer to provide } \\
\text { coaching and } \\
\text { scaffolding at critical } \\
\text { times }\end{array}$ \\
\hline $\begin{array}{l}\text { Implement a } \\
\text { working digital } \\
\text { innovation in a } \\
\text { business }\end{array}$ & $\begin{array}{l}\text { Require students to do a team-based } \\
\text { project with organisations within their } \\
\text { community where they are required to } \\
\text { implement a } \\
\text { real solution } \\
\text { Work in partnership with industry to } \\
\text { assess a segment that requires } \\
\text { innovation, and monitor the progress }\end{array}$ & $\begin{array}{l}\text { ICT/digital skills } \\
\text { Problem solving } \\
\text { and critical thinking } \\
\text { Life/job skills }\end{array}$ & $\begin{array}{l}\text { Authentic contexts } \\
\text { Authentic tasks - create } \\
\text { a polished product with } \\
\text { real-world relevance } \\
\text { Provide access to expert } \\
\text { performances and the } \\
\text { modelling of processes } \\
\text { Authentic assessment }\end{array}$ \\
\hline $\begin{array}{l}\text { Incorporate a } \\
\text { design-thinking } \\
\text { ethos }\end{array}$ & $\begin{array}{l}\text { The stages involve students in } \\
\text { discovering a challenge, interpreting the } \\
\text { context of the challenge, forming ideas, } \\
\text { building prototypes, testing the ideas } \\
\text { and developing a solution } \\
\text { Integrate with agile methodology and } \\
\text { provide clear guidance on the process } \\
\text { to be followed } \\
\text { Include value-proposition canvas and } \\
\text { guide students in process of } \\
\text { empathising with customers via } \\
\text { personas and empathy maps }\end{array}$ & $\begin{array}{l}\text { Core content } \\
\text { Creativity and } \\
\text { innovation }\end{array}$ & $\begin{array}{l}\text { Authentic tasks - } \\
\text { examine from different } \\
\text { perspectives with a } \\
\text { variety of resources } \\
\text { Provide access to } \\
\text { expert performances } \\
\text { and the modelling of } \\
\text { processes } \\
\text { Authentic assessment }\end{array}$ \\
\hline $\begin{array}{l}\text { Ensure that } \\
\text { students utilise } \\
\text { interdisciplinary } \\
\text { skills }\end{array}$ & $\begin{array}{l}\text { Innovation requires flexibility; it } \\
\text { demands experience and knowledge } \\
\text { that are both broad and deep } \\
\text { To understand problems, students need } \\
\text { to combine different academic } \\
\text { disciplines in a capstone project } \\
\text { Incorporate this to test for different } \\
\text { aspects in the assessment criteria }\end{array}$ & $\begin{array}{l}\text { Cross-disciplinary } \\
\text { Collaboration and } \\
\text { communication }\end{array}$ & $\begin{array}{l}\text { Authentic tasks - } \\
\text { integrate different subject } \\
\text { areas } \\
\text { Provide access to } \\
\text { expert performances } \\
\text { and the modelling of } \\
\text { processes } \\
\text { Provide multiple roles } \\
\text { and perspectives }\end{array}$ \\
\hline $\begin{array}{l}\text { Implement a } \\
\text { formal process } \\
\text { of reflection }\end{array}$ & $\begin{array}{l}\text { The use of reflection can assist in } \\
\text { anchoring learning and stimulating } \\
\text { deeper thinking and understanding } \\
\text { Assess the reflection process using } \\
\text { clear guidance in the rubric in terms of } \\
\text { expected outcomes }\end{array}$ & $\begin{array}{l}\text { Digital/ICT } \\
\text { Life/job skills }\end{array}$ & $\begin{array}{l}\text { Authentic tasks - } \\
\text { opportunities to reflect } \\
\text { Promote reflection to } \\
\text { enable abstractions to be } \\
\text { formed } \\
\text { Provide for authentic } \\
\text { assessment }\end{array}$ \\
\hline $\begin{array}{l}\text { Allow for } \\
\text { experimentation }\end{array}$ & $\begin{array}{l}\text { Innovation requires the willingness to } \\
\text { fail } \\
\text { Students are encouraged to try different } \\
\text { approaches and, when something fails, } \\
\text { they need to try another approach } \\
\text { without being penalised for it } \\
\text { Build steps into formative assessment } \\
\text { to encourage students to experiment } \\
\text { with different solutions }\end{array}$ & $\begin{array}{l}\text { Creativity and } \\
\text { innovation } \\
\text { Problem solving } \\
\text { and critical thinking }\end{array}$ & $\begin{array}{l}\text { Authentic tasks - } \\
\text { competing solutions and } \\
\text { a diversity of outcomes } \\
\text { Provide coaching and } \\
\text { scaffolding by the } \\
\text { lecturer at critical times }\end{array}$ \\
\hline $\begin{array}{l}\text { Ensure that } \\
\text { tasks culminate } \\
\text { in a capstone } \\
\text { project }\end{array}$ & $\begin{array}{l}\text { Involve students in projects that are } \\
\text { based on real-world, authentic } \\
\text { problems that are meaningful and } \\
\text { engaging }\end{array}$ & $\begin{array}{l}\text { Cross-disciplinary } \\
\text { Collaboration and } \\
\text { communication } \\
\text { Life/job skills }\end{array}$ & $\begin{array}{l}\text { Authentic contexts } \\
\text { Authentic tasks - } \\
\text { complex tasks performed } \\
\text { over a period of time }\end{array}$ \\
\hline
\end{tabular}




\begin{tabular}{|c|c|c|c|}
\hline Principle & Description and updates & $\begin{array}{l}\text { Skills sets } \\
\text { required for } \\
\text { principle }\end{array}$ & $\begin{array}{l}\text { Authentic learning } \\
\text { elements to support }\end{array}$ \\
\hline & $\begin{array}{l}\text { Projects ought to be structured to be } \\
\text { longer term and interdisciplinary, and } \\
\text { students need to provide their own } \\
\text { structures } \\
\text { - Apply agile methods } \\
\text { Students need to make use of digital } \\
\text { tools to produce high-quality end } \\
\text { products within a collaborative } \\
\text { environment } \\
\text { Assessments need to be built to take } \\
\text { the entire process into consideration, } \\
\text { and not just the end product, and to } \\
\text { allow for multiple solutions }\end{array}$ & & $\begin{array}{l}\text { Provide for authentic } \\
\text { assessment }\end{array}$ \\
\hline $\begin{array}{l}\text { Partner with } \\
\text { entrepreneurs }\end{array}$ & $\begin{array}{l}\text { - } \quad \begin{array}{l}\text { Partner with entrepreneurial businesses } \\
\text { that contribute to their community }\end{array} \\
\text { - } \quad \begin{array}{l}\text { Encourage a focus on social awareness } \\
\text { Have a strong emphasis on ethical } \\
\text { business practices }\end{array}\end{array}$ & $\begin{array}{l}\text { Life and job skills } \\
\text { EQ and ethics } \\
\text { Cultural awareness }\end{array}$ & $\begin{array}{l}\text { Authentic tasks - } \\
\text { competing solutions and } \\
\text { a diversity of outcomes } \\
\text { Provide multiple roles } \\
\text { and perspectives }\end{array}$ \\
\hline
\end{tabular}

(Source: Van den Berg 2018)

\section{CONCLUSION}

This article explored the complexities of our higher education environment, coupled with the explosion of digital technologies and, at the centre, the students and their well-being. The impact of digital innovation on IS education was studied to identify principles to design a course that will equip students to use technology to improve the effectiveness of business, the environment and society.

To achieve the objectives, the skills to equip IS students to better perform their future roles in the digital economy were identified. The skills identified included core content knowledge, digital skills, cross-disciplinary skills, communication, collaboration, problem solving, critical thinking, innovation, creativity, life and job skills and emotional intelligence.

The teaching and learning environment to teach such skills was subsequently explored to outline the principles of authentic learning. This culminated in the design of principles to include in the design of a course to teach digital innovation. These principles were tested and refined during three iterations of a DBR study, as depicted in the article.

The impact of global trends in digital innovation on the IS curriculum, the skills required to develop competent digital innovators, and the teaching and learning interventions required in IS were foregrounded.

The article concluded with an overview of the eight design principles developed to enrich the IS curriculum to enable digital innovation capacity.

\section{Disclosure statement}

No potential conflict of interest was reported by the author. 


\section{REFERENCES}

Adams Becker, Samantha, Michele Cummins, Annie Davis, Alex Freeman, C. Glesinger Hall and Vidya Ananthanarayanan. 2017. NMC horizon report: 2017 higher education edition. The New Media Consortium.

Amiel, Tel and Thomas C. Reeves. 2008. Design-based research and educational technology: Rethinking technology and the research agenda. Educational Technology \& Society 11: 29-40.

Bates, Anthony William. 2015. Teaching in the digital age. Vancouver BC: Tony Bates Associates Ltd.

Benkert, van Dam, Nick. 2015. Experiential learning: What's missing in most change programs experiential. McKinsey Quarterly August.

Bharadwaj, Anandhi, Omar A. El Sawy, Paul A. Pavlou and N. Venkatraman. 2013. Visions and voices on emerging challenges in digital business strategy. MIS Quarterly 37 (May): 1-30.

Boud, David and Elizabeth Molloy. 2013. Rethinking models of feedback for learning: The challenge of design. Assessment \& Evaluation in Higher Education 38(6): 698-712.

Braun, Virginia and Victoria Clarke. 2006. Using thematic analysis in psychology." Qualitative Research in Psychology 3(2): 77-101.

Briggs, Saga. 2013. Innovators: 25 Ways to prepare students for a changing job landscape. InformED. http://www.opencolleges.edu.au/informed/features/educating-innovators/

Brynjolfsson, Erik and Andrew McAfee. 2014. The second machine age. $1^{\text {st }}$ Edition. New York, USA: Norton and Company.

Cain, William, Danah Henriksen and Deep-Play Research Group. 2017. Uncreativity: A discussion on working creativity before and after ideation with Dr. Chris Bilton. TechTrends 61(2): 101-105.

Creswell, John W. and Vicki L. Plano Clark. 2011. Designing and conducting mixed methods research. $2^{\text {nd }}$ Edition. Sage. Los Angeles.

Fichman, Robert G., Brian L. Dos Santos and Zhiqiang (Eric) Zheng. 2014. Digital innovation as a fundamental and powerful concept in the information systems curriculum. MIS Quarterly 38(2): 329-A15

Gray, David E. 2004. Doing research in the real world. Sage.

Green, James. 2015. The opportunity analysis canvas. $3^{\text {rd }}$ Edition. University of Maryland: Venture Artisans.

Hartman, Yvonne and Sandy Darab. 2012. A call for slow scholarship: A case study on the intensification of academic life and its implications for pedagogy. Review of Education, Pedagogy, and Cultural Studies 34(1-2): 49-60.

Herrington, Jan. 1997. Authentic learning in interactive multimedia environments." http://www.academia.edu/176919/Authentic_learning_in_interactive_multimedia_environments

Herrington, Jan, Thomas C. Reeves and Ron Oliver. 2010. A guide to authentic e-learning. British Journal of Educational Technology 42: 167-84.

Herrington, Jan and Thomas C. Reeves. 2011. Using design principles to improve pedagogical practice and promote student engagement." ASCILITE 2011 - The Australasian Society for Computers in Learning in Tertiary Education, 594-601.

Hevner, Alan and Samir Chatterjee. 2010. Design science research in information systems. In Design research in information systems, 9-22. Springer US.

Johnson, Larry, Samantha Adams Becker, Victoria Estrada and Alex Freeman. 2016. NMC horizon report: 2016 library edition. The New Media Consortium.

Kereluik, Kristen, Punya Mishra, Chris Fahnoe and Laura Terry. 2013. What knowledge is of most worth. Journal of Digital Learning in Teacher Education 29(4): 127-140.

Koehler, Matthew J. and Punya Mishra. 2009. "What is technological pedagogical content knowledge (TPACK)?" Contemporary Issues in Technology and Teacher Education 9(1): 60-70. 
McKenney, Susan and Thomas C. Reeves. 2012. Conducting educational design research. Routledge.

Miles, Matthew B., A. Michael Huberman, Michael A. Huberman and Michael Huberman. 1994. Qualitative data analysis: An expanded sourcebook. Sage.

Montresor, Fulvia. 2016. The digital transformation of industries. In World Economic Forum. Davos: World Economic Forum.

Nanterme, Pierre and Paul Daugherty. 2017. The era of the intelligent enterprise." Accenture New Technology Vision. New York, USA.

Osborne, Richard, Elisabeth Dunne and Paul Farrand. 2013. Integrating technologies into "authentic" assessment design: An affordances approach. Research in Learning Technology 21(1): 21986.

P21 see Partnership for 21st Century Skills

Partnership for 21st Century Skills. 2015. "Framework for 21st Century Learning," 2. https://doi.org/ http://www.21 stcenturyskills.org/documents/framework_flyer_updated_jan_09_final-1.pdf

Redecker, Christine, Miriam Leis, Matthijs Leendertse, Yves Punie, Govert Gijsbers, Paul A. Kirschner, Slavi Stoyanov and Bert Hoogveld. 2011. The future of learning: Preparing for change. Luxembourg: Office of the European Union.

Rogers, Everett M. 1995. Diffusion of innovations. Macmillian Publishing Co.

Rosenthal, Paul and Kewal Dhariwal. 2015. Proposed IS 2015 model curriculum. The Business Forum Journal.

Sharpe, Rhona, Helen Beetham and Sara De Freitas. 2010. Rethinking learning for a digital age: How learners are shaping their own experiences. Routledge.

Stansberry, Susan L. 2017. Authentic teaching with technology through situated learning. Journal of Formative Design in Learning 1(1): 16-30.

Topi, Heikki, Joseph S. Valacich, Ryan T. Wright, Kate Kaiser, Jay F. Nunamaker, Janice C. Sipior and Gert Jan de Vreede. 2010. IS 2010: Curriculum guidelines for undergraduate degree programs in information systems." Communications of the Association for Information Systems 26(1): 359428.

Van den Berg, Carolien L. 2018. A framework for teaching digital innovation skills to South African information systems students," PhD dissertation. University of the Western Cape.

Van Dijk, Geke. 2010. Design ethnography: Taking inspiration from everyday life. Service Design Thinking. London and Amsterdam.

Venkatesh, Viswanath, Susan Scott and Michael Barrett. 2013. Bridging the qualitative-quantitative divide: Guidelines for conducting mixed methods research in information systems. Management Information Systems Quarterly 37(1): 21-54.

Vygotsky, Lev S. 1978. Mind in society. Cambridge, MA: Harvard University Press.

Wang, Feng and Michael J. Hannafin. 2005. Design-based research and technology-enhanced learning environments. Educational Technology Research and Development 53(4): 5-23. 